\title{
FUSARIOTOXINS IN FEED OF DAIRY COWS AND CARRY-OVER TO MILK AND IMPACT ON RAW MILK QUALITATIVE INDICATORS
}

\author{
Rimvydas FALKAUSKAS, Department of Food Safety and Quality, Faculty of Veterinary, Veterinary Academy of Lithuanian \\ University of Health Sciences, A. Mickevičiaus g. 9, LT-44308 Kaunas, Lithuania, rimvydas.falkauskas@lsmuni.lt (corresponding \\ author) \\ Violeta BALIUKONIENÉ, Department of Food Safety and Quality, Faculty of Veterinary, Veterinary Academy of Lithuanian \\ University of Health Sciences, A. Mickevičiaus g. 9, LT-44308 Kaunas, Lithuania, violeta.baliukoniene@ lsmuni.lt \\ Bronius BAKUTIS, Department of Food Safety and Quality, Faculty of Veterinary, Veterinary Academy of Lithuanian University of \\ Health Sciences, A. Mickevičiaus g. 9, LT-44308 Kaunas, Lithuania, bronius.bakutis@1smuni.lt \\ Jurgita JOVAIŠIENE், Department of Food Safety and Quality, Faculty of Veterinary, Veterinary Academy of Lithuanian University \\ of Health Sciences, A. Mickevičiaus g. 9, LT-44308 Kaunas, Lithuania, jurgita.jovaisiene@1smuni.lt
}

The research aims of this study were to determine and to evaluate the effect of feed contaminated with different concentrations of fusariotoxins (zearalenone (ZEA), deoxynivalenol (DON) on the quality of milk investigate concentration zearalenone in cow milk samples. Feed and milk samples were collected from dairy farms which were the high Total Bacterial Count (TBC) and Somatic Cell Count (SCC) in milk. Feed samples were tested by TLC (Romer Labs methods). The zearalenone (ZEA) in the milk was measured by ELISA test, RIDASCREEN $®$ Zearalenon (R-Biopharm AG). The milk qualitative indicators testing was conducted by public enterprise „Pieno tyrimai“ (Lithuania). From 12 dairy cow farms, which have high TBC and SCC, were selected feed samples for detection of fusariotoxins. Average ZEA concentration in feed was $496.25 \pm 51 \mu \mathrm{g} / \mathrm{kg}(\mathrm{p}<0.05)$, DON average concentration in feed was $65.31 \pm 12 \mu \mathrm{g} / \mathrm{kg}(\mathrm{p}<0.05)$. Higher amount TBC in milk samples were in those farms where was detection ZEA and DON concentration. As a result, we can assume that the higher TBC in milk samples than $221 \pm 20$ thous. $\mathrm{CFU} / \mathrm{ml}$ was find in farms where in feed samples was detected the higher ZEA concentration than $700 \pm 50 \mu \mathrm{g} / \mathrm{kg}(\mathrm{p}<0.05)$. The highest levels than $650 \pm 42$ of SCC in milk were found when the feed samples were contaminated ZEA $-700 \pm 50 \mu \mathrm{g} / \mathrm{kg}(\mathrm{p}<0.05)$ and more. It can also be observed that the higher the ZEA concentration in the sample is, the higher the amount of SCC follow s. Comparing concentration ZEA in feed and in milk established percent from 0.01 to $0.31 \%(\mathrm{p}<0.05)$. The highest levels of SCC and TBC were found in samples with high concentrations of ZEA. In $16 \%$ milk samples we detected ZEA, concentration was from $0.08 \mu \mathrm{g} / \mathrm{l}$ to $0.4 \mu \mathrm{g} / \mathrm{l}$.

Keywords: deoksinivalenol, feed, milk, zearalenone.

\section{INTRODUCTION}

Dairying is one of the leading farming branches not only in Lithuania but in the whole world as well. In 2018 alone 1363.01 thousand tonnes were milked in Lithuania. Ministry of Agriculture assert this is the average $7000 \mathrm{~kg}$ out of one cow which is $1.5 \%$ more than it was in 2017. Increasing need for milk shows that this industry will continue to grow by improving animals genetics and it`s living standards. Increased amount of milk means more production and in order to establish quality products, the quality material is a must (Ministry of Agriculture, 2019).

When production animals are feeding total mixed ration (TMR) feed with low concentrations of mycotoxin, impact to animals researched not enough, even less researched cow organism response, when feeding with low concentrations of mycotoxins for a long time. Need to know in what quantities of mycotoxins organism are accumulative himself. Mycotoxin negative impact to animal wellness is not definitively clear and what mycotoxin metabolites parts are crossing the organism protective barriers and passes into milk.

Zearalenone is rapidly absorbed from the gastrointestinal tract in mammals. In the small intestine and in the liver, urea diphosphate-glucuronosyltransferase (UGTs) and sulphotransferase (SULTs) are combined with glucuronic acid and sulphates, part of zearalenone and its reduced metabolites. This reduces the parent compound's uptake into the bloodstream (EFSA, 2011).

The effects of mycotoxins vary from animal species to age group, gender, physiological characteristics. Zearalenone is thought to be more susceptible to fetal and neonatal effects due to underdeveloped metabolism and other physiological features. A study of various species of domestic animals (horses, cattle, sheep, pigs) and laboratory tests revealed that pigs are the most sensitive animal species for this toxin. Females are more sensitive than males. Higher levels of $\alpha$-zearalenol in females may affect their sensitivity.

Copyright (C) 2019 The Authors. Published by Vytautas Magnus University. This is an open-access article distributed under the terms of the Creative Commons Attribution License (CC-BY 4.0), which permits unrestricted use, distribution, and reproduction in any medium, provided the original author and source are credited. 
Research aim - to determine and to evaluate the effect of feed contaminated with different concentrations of fusariotoxins (zearalenone, deoxynivalenol) on the quality of milk and zearalenone concentration in milk.

\section{MATERIAL AND METHODS}

From 12 Lithuanian dairy farms, were found raw milk qualitative indicators deviations (TBC, SCC), were collected TMR (total mixed ration) feed samples and were collected milk samples $(\mathrm{N}=10)$. Before milking the first jets of milk was dripping, and milk samples were aseptically taken into sterile tubes, according to milk samples taking rules (LST EN ISO 707:1999+P:2008 milk and milk production. Rules of milk samples).

Mycotoxins (ZEA and DON) concentrations were detected in LUHS VA Mycotoxicology laboratory, applying TLC method according to Romer Labs. Inc. (Austria) methodology.

ZEA concentration in milk was determined by commercial ELISA kit „RIDASCREEN@ Zearalenon“ (R-Biopharm AG, Germany), according to the manufacturer's methodology. The results were scanned spectrophotometer to $450 \mathrm{~nm}$ light wavelength filter by absorption. Final results were get comparing sample optical density with average optical density of positive control. Limit of detection $-0.080 \mu \mathrm{g} / \mathrm{L}$. Until the start testing milk samples, were stored in minus $18^{\circ} \mathrm{C}$.

The quantitative indicators of milk were tested in SE (state-owned enterprise) „Pieno tyrimai”. Milk samples were analyzed for fat content (\%), protein content (\%), lactose content (\%), urea content (mg/100 ml). Total Bacterial Count (TBC) and Somatic Cell Count (SCC) parameters are calculated by applying regulation (EB) No. 853/2004 II annex IX section in chapter III requirements.

For the statistical analysis was used descriptive statistics and-independent sample " $T$ " test using SPSS software (version 17.0 for Windows, SPSS Inc., Chicago, IL, USA).

\section{RESULTS AND DISCUSSION}

From dairy farms were collected TMR (total mixed ration) feed samples. In these samples were detected fusariotoxins (ZEA and DON). Data was showed that in TMR (Fig.1) was from 12 TMR samples eleven were contaminated with ZEA and seven samples were contaminated with DON.

Based on data from the scientific literature Grenier with other scientists (2011) the feed samples analyzed may not only be contaminated ZEA and DON, but also other non-identifiable mycotoxins or their metabolites which, due to synergistic interaction with each other, may potentiate ZEA and DON undesirable effects on cows. We also noticed that ZEA concentrations in the samples were higher if we compared to the other mycotoxin (DON) tested. The study data are in agreement with that of many authors and also indicate that ZEA is commonly detected in feed (Arslanbas et al, 2010; Busk et al, 2012; Oliver et al, 2012; Stopa et al, 2014).

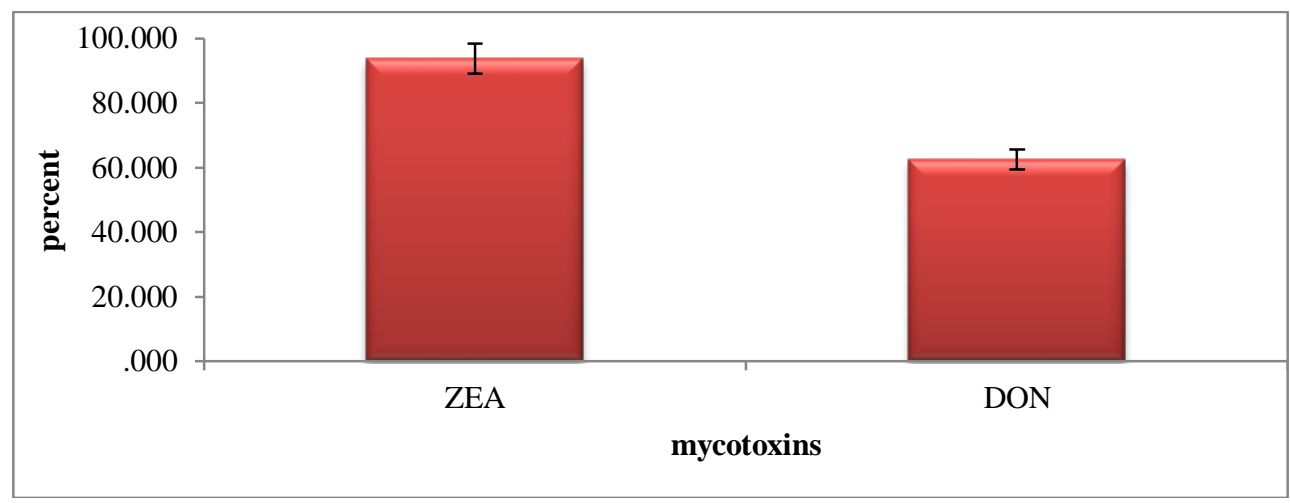

Figure 1. The presence of total mixed ration (TMR) feed samples contaminated with ZEA and DON

According to the Lithuanian Minister of Agriculture order (Concerning the Minister of Agriculture June 4 order no. 3d-225 on the approval of a technical regulation on mandatory safety requirements for products intended for animal nutrition and Ministerial Decree of the Minister of Agriculture of 2001 June 21 order no. 206, "repealing the technical regulation on mandatory feed safety requirements for feed", repealed 19 March 2012. No. 3D-183) maximum allowed ZEA and DON limits in complete feed for dairy cows $-500 \mu \mathrm{g} / \mathrm{kg}$. In the study were determined, that in $33.3 \pm 0.1 \%$ (in 4 from 12 samples) feeds samples were exceeded the ZEA allowed maximum limits. The allowed maximum limits of DON in feed samples not detection (Fig. 2).

Dependency in raw milk samples between quantitative indicator of milk (fat, protein and lactose) and mycotoxins (ZEA and DON) concentration in TMR feed not detection. Data in Table 1. 

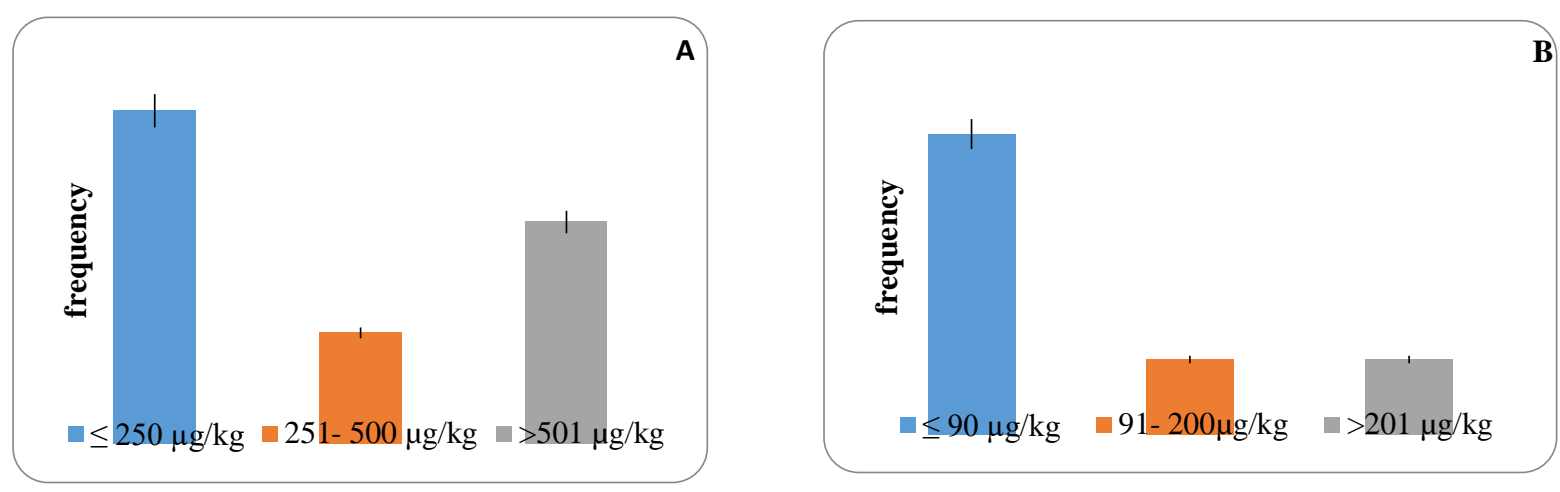

Figure 2. ZEA (A) and DON (B) concentration frequency in total mixed ration (TMR) feed samples

Table 1. Chemical indicators in milk samples from farms and mycotoxins ZEA and DON in TMR samples

\begin{tabular}{|c|c|c|c|c|c|c|c|}
\hline \multirow[b]{2}{*}{ Farm } & \multicolumn{5}{|c|}{ Milk samples } & \multicolumn{2}{|c|}{$\begin{array}{c}\text { Total mixed ration } \\
\text { (TMR) feed samples }\end{array}$} \\
\hline & $\begin{array}{c}\text { Fat content } \\
(\%)\end{array}$ & $\begin{array}{c}\text { Protein } \\
\text { content }(\%)\end{array}$ & $\begin{array}{c}\text { Lactose } \\
\text { content }(\%)\end{array}$ & $\begin{array}{c}\text { Urea } \\
\text { content } \\
(\mathrm{mg} / 100 \mathrm{ml})\end{array}$ & $\mathrm{pH}$ & ZEA, $\mu \mathrm{g} / \mathrm{kg}$ & $\begin{array}{l}\mathrm{DON} \\
\mu \mathrm{g} / \mathrm{kg}\end{array}$ \\
\hline 1 & $4 \pm 0.25$ & $3,34 \pm 0.18$ & $4.58 \pm 0.1$ & $30 \pm 2.5$ & $6.65 \pm 0.12$ & $1000 \pm 150$ & $100 \pm 12$ \\
\hline 2 & $3.7 \pm 0.21$ & $3.25 \pm 0.14$ & $4.46 \pm 0.2$ & $8 \pm 2.2$ & $6.79 \pm 0.14$ & $170 \pm 32$ & $50 \pm 19$ \\
\hline 3 & $3.7 \pm 0.21$ & $3.25 \pm 0.12$ & $4.46 \pm 0.14$ & $8 \pm 2.2$ & $6.79 \pm 0.09$ & $170 \pm 32$ & 0 \\
\hline 4 & $4.21 \pm 0.09$ & $3.31 \pm 0.15$ & $4.56 \pm 0.08$ & $23 \pm 2.4$ & $6.67 \pm 0.05$ & $830 \pm 75$ & $250 \pm 41$ \\
\hline 5 & $4.11 \pm 0.15$ & $3.48 \pm 0.08$ & $4.55 \pm 0.03$ & $12 \pm 1.8$ & $6.64 \pm 0.06$ & $170 \pm 32$ & 0 \\
\hline 6 & $3.77 \pm 0.38$ & $3.31 \pm 0.24$ & $4.67 \pm 0.15$ & $18 \pm 3.1$ & $6.62 \pm 0.01$ & $300 \pm 53$ & 0 \\
\hline 7 & $3.77 \pm 0.29$ & $3.31 \pm 0.09$ & $4.67 \pm 0.2$ & $15 \pm 2.5$ & $6.62 \pm 0.09$ & 0 & 0 \\
\hline 8 & $4.52 \pm 0.24$ & $3.38 \pm 0.11$ & $4.49 \pm 0.07$ & $25 \pm 2.2$ & $6.71 \pm 0.05$ & $500 \pm 61$ & $50 \pm 19$ \\
\hline 9 & $4.4 \pm 0.8$ & $3.32 \pm 0.10$ & $4.58 \pm 0.06$ & $24 \pm 4.1$ & $6.63 \pm 0.05$ & $830 \pm 75$ & $125 \pm 30$ \\
\hline 10 & $4.47 \pm 0.42$ & $3.42 \pm 0.06$ & $4.49 \pm 0.11$ & $20 \pm 3.7$ & $6.68 \pm 0.06$ & $700 \pm 68$ & $250 \pm 41$ \\
\hline 11 & $4.2 \pm 0.31$ & $3.4 \pm 0.02$ & $4.56 \pm 0.17$ & $12 \pm 2.1$ & $6.67 \pm 0.04$ & $130 \pm 24$ & 0 \\
\hline 12 & $4.24 \pm 0.22$ & $2.99 \pm 0.07$ & $4.2 \pm 0.03$ & $9 \pm 1.9$ & $6.7 \pm 0.07$ & $200 \pm 38$ & $50 \pm 19$ \\
\hline $\mathbf{R}$ & & $0.196^{*}$ & & & $-0.075^{*}$ & $0,196^{*}$ & $-0.075^{*}$ \\
\hline $\mathbf{R}$ & $0.501 *$ & & & $0.524 *$ & & $0.501 *$ & $0.524 *$ \\
\hline $\mathbf{R}$ & & $0.107 *$ & $0.141^{*}$ & & & $0.141 *$ & $0.107 *$ \\
\hline $\mathbf{R}$ & & & $-0.053 *$ & $0.865^{*}$ & & $0.865^{*}$ & $-0.053 *$ \\
\hline $\mathbf{R}$ & $0.534 *$ & & & & $-0.244^{*}$ & $-0.244 *$ & $0.534 *$ \\
\hline median & 4.155 & 3.315 & 4.555 & 16.5 & 6.67 & 250 & 50 \\
\hline $\min$ & 3.7 & 2.99 & 4.2 & 8 & 6.62 & 0 & 0 \\
\hline $\max$ & 4.52 & 3.48 & 4.67 & 30 & 6.79 & 1000 & 250 \\
\hline
\end{tabular}

The biggest total bacterial count (TBC) was found in milk sample, of those farms in which TMR feed samples detection high ZA concentrations. Observed, that when in feed samples are high ZEA concentration, respectively in milk samples TBC are also higher. Correlation between TBC in milk and ZEA in TMR feed was detected average negative $(\mathrm{r}=-0.413)$. Correlation between TBC in milk and DON in TMR feed detected - weak negative ( $r=-0.362)$. Correlation between SCC in milk and DON in feed was detected - negative.

The biggest somatic cell count (SCC) was found in milk samples, of those farms in which TMR feed samples was detection high ZEA concentration. Evaluating SCC in milk and DON in feed addictions inconspicuous, because on detection high DON concentration in feed samples in milk samples SCC increasing did not have. In feed samples which ZEA concentration detection more than $600 \mu \mathrm{g} / \mathrm{kg}$, together with DON when concentration detection more that $100 \mu \mathrm{g} / \mathrm{kg}$ in milk samples SCC detection more than 2 times exceed SCC norm in milk (norm to 400 thous./ml). Correlation between SCC in milk and ZEA in feed was detected - strong positive $(r=0.902)$. Correlation between SCC in milk and DON in feed - strong positive ( $\mathrm{r}=0.801)$.

According to Food and Veterinary Office of the European Commission (FVO) to conclusions of the audit of the dairy sector and recommendations. Raw milk purchased in Lithuania must not exceed the total bacterial count (TBC) 100 thous. CFU/ml. The results showed that $33.3 \%$ of selected milk samples exceeded SCC norm and $16.7 \%$ TBC norm (Table 2). 
BC and SCC levels were found to be higher in milk samples from farms with high ZEA levels in feed. Arslanb, with other scientists (2010) and Busk with other scientists (2012), also agrees that ZEA can influence the qualitative indicators of influenced milk (TBC, SCC).

Table 2. Average TBC and SCC amount in milk samples and mycotoxins ZEA and DON in TMR samples from Lithuanian dairy farms

\begin{tabular}{|c|c|c|c|c|}
\hline \multirow{2}{*}{ Farm } & \multicolumn{2}{|c|}{ Milk samples } & \multicolumn{2}{|c|}{$\begin{array}{c}\text { Total mixed ration (TMR) feed } \\
\text { samples }\end{array}$} \\
\hline & $\begin{array}{c}\text { Total Bacterial Count (TBC), } \\
\text { thous. CFU/ml }\end{array}$ & $\begin{array}{c}\text { Somatic Cell Count (SCC), } \\
\text { thous./ml }\end{array}$ & $\mathrm{ZEA}, \mu \mathrm{g} / \mathrm{kg}$ & $\mathrm{DON}, \mu \mathrm{g} / \mathrm{kg}$ \\
\hline 1 & $61 \pm 5.1$ & $814 \pm 25$ & $1000 \pm 150$ & $100 \pm 12$ \\
\hline 2 & $201 \pm 15$ & $351 \pm 19$ & $170 \pm 32$ & $50 \pm 19$ \\
\hline 3 & $201 \pm 15$ & $320 \pm 23$ & $170 \pm 32$ & 0 \\
\hline 4 & $30 \pm 3.1$ & $650 \pm 34$ & $830 \pm 75$ & $250 \pm 41$ \\
\hline 5 & $67 \pm 5.4$ & $217 \pm 14$ & $170 \pm 32$ & 0 \\
\hline 6 & $17 \pm 1.7$ & $340 \pm 27$ & $300 \pm 53$ & 0 \\
\hline 7 & $17 \pm 1.7$ & $340 \pm 27$ & 0 & 0 \\
\hline 8 & $82 \pm 4.2$ & $378 \pm 25$ & $500 \pm 61$ & $50 \pm 19$ \\
\hline 9 & $9 \pm 0.8$ & $891 \pm 64$ & $830 \pm 75$ & $125 \pm 30$ \\
\hline 10 & $29 \pm 1.3$ & $850 \pm 51$ & $700 \pm 68$ & $250 \pm 41$ \\
\hline 11 & $87 \pm 4.3$ & $250 \pm 11$ & $130 \pm 24$ & 0 \\
\hline 12 & $86 \pm 4.2$ & $350 \pm 13$ & $200 \pm 38$ & $50 \pm 19$ \\
\hline $\mathbf{R}$ & & $0.902 *$ & $0.902 *$ & \\
\hline $\mathbf{R}$ & & $0.801 *$ & & $0.801 *$ \\
\hline $\mathbf{R}$ & $-0.362 * *$ & & & $-0.362 * *$ \\
\hline $\mathbf{R}$ & $-0.413 * *$ & & $-0.413 * *$ & \\
\hline mediana & 64 & 350.5 & 250 & 50 \\
\hline $\min$ & 9 & 217 & 0 & 0 \\
\hline $\max$ & 201 & 891 & 1000 & 250 \\
\hline
\end{tabular}

ZEA concentration in milk samples vary of range from $0.081 \mu \mathrm{g} / 1$ to $0.4 \mu \mathrm{g} / \mathrm{l}$. In evaluating what part ZEA detection in milk sample, when in feed samples ZEA was detection, we found when in feed ZEA concentration was $130 \mu \mathrm{g} / \mathrm{kg}$, in milk $-0.4 \mu \mathrm{g} / \mathrm{l}$, but when in feed (TMR) ZEA concentration was $700 \mu \mathrm{g} / \mathrm{kg}$, in milk was found - $0.081 \mu \mathrm{g} / \mathrm{l}$. Correlation between ZEA in feed (TMR) and ZEA in milk was detected - strong negative ( $r=-0.90)(>0.05)$. So for this negative correlation in ZEA in feed (TMR) and ZEA in milk needed to conduct further research and evaluate others factors (age, animal physiology and etc.)

Noticed that in $66.67 \pm 0,01 \%$ tested milk samples ZEA concentration found less than the limit of detection, and in $25 \%$ of milk samples ZEA concentration found more that $0.091 \mu \mathrm{g} / \mathrm{l}$.

The concentration of ZEA in milk samples ranged from $0.08 \mu \mathrm{g} / 1$ to $0.4 \mu \mathrm{g} / 1$ and the percentage of milk samples contaminated with ZEA was $16 \%$. A group of Croatian scientists (Pleadin et al, 2017) who also quantified ZEA in milk samples. Based on their studies, they also determined mycotoxin ZEA levels in milk samples, with concentrations ranging from $0.3 \mu \mathrm{g} / \mathrm{L}$ to $88.6 \mu \mathrm{g} / \mathrm{L}$ (Pleadin et al., 2017). The maximum level for ZEA in milk is not regulated, but according to Commission Regulation (EC) No. Amending Regulation (EC) No 1881/2006 setting maximum levels for certain contaminants in foodstuffs intended for infants and young children as a foodstuff containing $20 \mu \mathrm{g} / \mathrm{kg}$ of processed cerealbased foods.

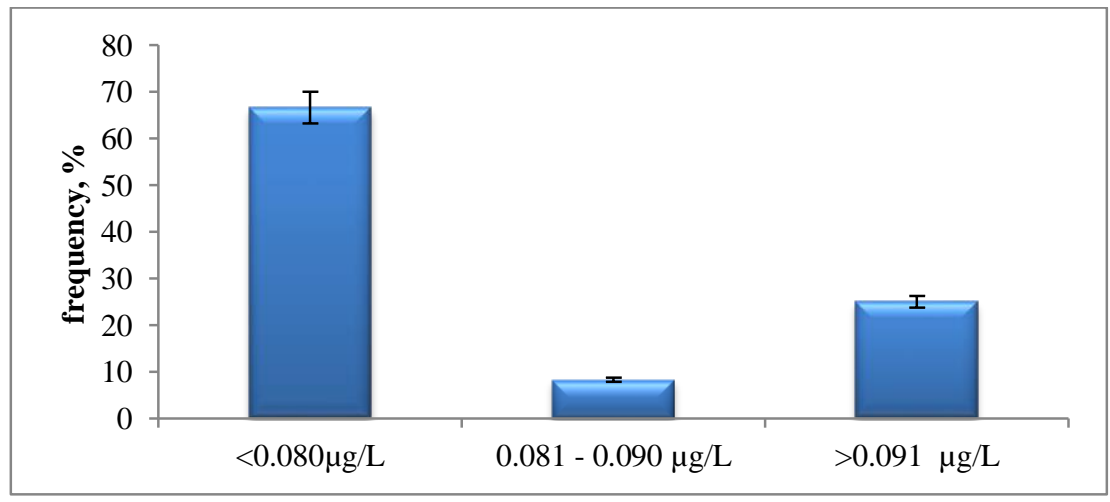

Figure 3. ZEA concentration frequency percent in milk samples 


\section{CONCLUSIONS}

In tested dairy farms TMR feed from feeding table contamination of ZEA more that $90 \%$ ( 9 from 10 samples), or contamination of DON in TMR feed more that $60 \%$ ( 6 from 10 samples). Correlation between TBC in milk and ZEA in feed - average negative $(r=-0.413)$ with DON - weak negative $(r=-0.362)$. Correlation between SCC in milk and ZEA in feed - very strong positive $(r=0.902)$ and with DON - strong positive $(r=0.801)$. Was detected that ZEA quantity in milk samples - very strong negative $(\mathrm{r}=-0.90)$. For this negative correlation in ZEA in feed (TMR) and ZEA in milk needed to conduct further research and evaluate others factors (age, animal physiology and etc.)

\section{REFERENCES}

1. Arslanbas E., Baydan E. Domuzlarda Yaygin Gorulen Zehirlenmeler:1. 2010. Mikotoksin Zehirlenmeleri. Veteriner Hekimler Derneği Dergisi, Vol. 81(1), pp. 9-12.

2. Busk Ø. L., Frizzell C., Verhaegen S., Uhlig S., Connolly L., Ropstad E., Sørlie M., 2012. Cytosol protein regulation in H295R steroidogenesis model induced by the zearalenone metabolites, alfa- and beta-zearalenol. Toxicon, Vol. 59, pp. 17-24. https://doi.org/10.1016/j.toxicon.2011.10.007

3. EFSA Journal 2011;9(6):2197, 2011. Scientific Opinion on the risks for public health related to the presence of zearalenone in food. EFSA Panel on Contaminants in the Food Chain, European Food Safety Authority (EFSA), Parma, Italy. https://doi.org/10.2903/j.efsa.2011.2197

4. Grenier B, Oswald IP. 2011. Mycotoxin co-contamination of food and feed: Meta-analysis of publications describing toxicological interactions. World Mycotoxin Journal, Vol. 4, pp. 285-313. https://doi.org/10.3920/WMJ2011.1281

5. Monkeviciene I. 1996. Karviu didziojo prieskrandzio turinio fermentaciniu procesu aktyvumo ir pasaru kokybes itaka virskinamumui. Daktaro disertacija. Kaunas (In Lithuanian)

6. Oliver W.T., Miles J.R.,. Diaz D.E., Dibner J.J., Rottinghaus G.E., Harrell R.J. 2012. Zearalenone enhances reproductive tract development, but does not alter skeletal muscle signaling in prepubertal gilts. Animal Feed Science and Technology, Vol. 174, pp. 79- 85 https://doi.org/10.1016/j.anifeedsci.2012.02.012

7. Pleadin J.,Vulic A., Zadravec M.,Lešic T., Benic M., Tkalec J.V., Vahčic N., 2017. Presence of Fusarium mycotoxins in feedstuffs and cow milk sampled from Croatian farms during 2015. Mljekarstvo, Vol. 67 (2), pp. $102-111$. https://doi.org/10.15567/mljekarstvo.2017.0202

8. Stopa, E., Gajęcka, M., Babińska, I., Zielonka, Ł., Gajęcki, M., 2014. The effect of experimental exposure to low doses of zearalenone on uterine histology and morphometry in prepubertal bitches. Theriogenology, Vol. 82, pp. 537-545. https://doi.org/10.1016/j.theriogenology.2014.05.002

9. Zemes ukio ministerija. Available at www.zum.lt (accessed on 27/02/2019). (In Lithuanian) 